\title{
ECONOMY OF A RETROFIT SOLAR SYSTEM
}

J. M. Schreyer

\section{MASTER}

OAK RIDGE Y-12 PLANT

OAK RIDGE. TENNESSEE 


\section{DISCLAIMER}

This report was prepared as an account of work sponsored by an agency of the United States Government. Neither the United States Government nor any agency Thereof, nor any of their employees, makes any warranty, express or implied, or assumes any legal liability or responsibility for the accuracy, completeness, or usefulness of any information, apparatus, product, or process disclosed, or represents that its use would not infringe privately owned rights. Reference herein to any specific commercial product, process, or service by trade name, trademark, manufacturer, or otherwise does not necessarily constitute or imply its endorsement, recommendation, or favoring by the United States Government or any agency thereof. The views and opinions of authors expressed herein do not necessarily state or reflect those of the United States Government or any agency thereof. 


\section{DISCLAIMER}

Portions of this document may be illegible in electronic image products. Images are produced from the best available original document. 
Reference to a company or product name does not imply approval or recommendation of the product by Union Carbide Corporation or the U.S. Energy Research and Development Administration to the exclusion of others that mav meet specifications.

Printed in the United States of America. Available from

National Technical Information Service

U.S. Department of Commerce

5285 Port Royal Road, Springfield, Virginia 22161

Price: Printed Copy $\$ 3.50$; Microfiche $\$ 3.00$

$$
\$ 4.00
$$

This report was prepared as an account of work sponsored by the United States Government. Neither the United States nor the Energy Research and Development Administration, nor any of their employees, nor any of their contractors, subcontractors, or their employees, makes any warranty, express or implied, or assumes any legal liability or responsibility for the accuracy, completeness or usefulness of any information, apparatus, product or process disclosed, or represents that its use would not infringe privately owned rights. 
Date of Issue: September 9, 1977

Distribution Category: UC-59

\title{
ECONOMY OF A RETROFIT SOLAR SYSTEM
}

\author{
J. M. Schreyer
}

Senior Technical Advisor

Y.12 Dovolopmont Division

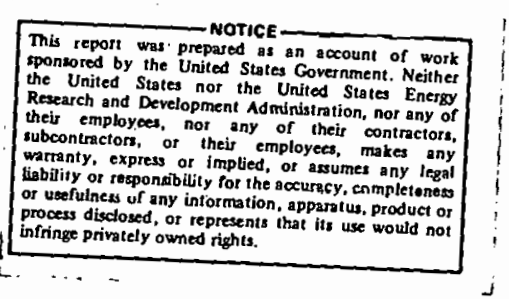

Oak Ridge $Y-12$ Plant

P. O. Box Y, Oak Ridge, Tennessee 37830

Prepared for the US Energy Research and Development Administration Under US Government Contract W-7405-eng-26 


\begin{abstract}
A privately financed solar-augmented hot water system has been demonstrated to pay off in less than 10 years if a loan is obtained at $10.5 \%$ interest. Calculations were made on the assumption that electricity costs $5 \notin$ per $\mathrm{kWh}$ and water consumption averages 30 gallons per day (using current technology on an existing dwelling in Tennessee).
\end{abstract}




\section{CONTENTS}

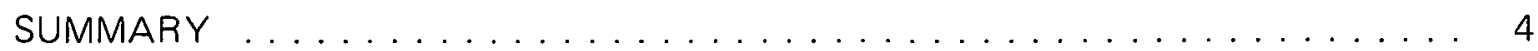

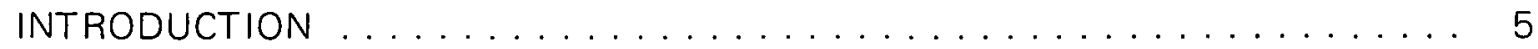

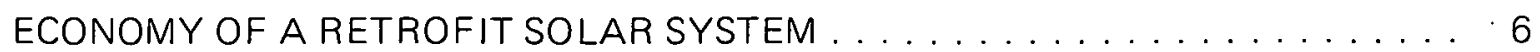

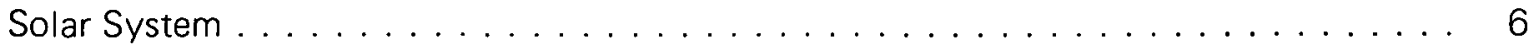

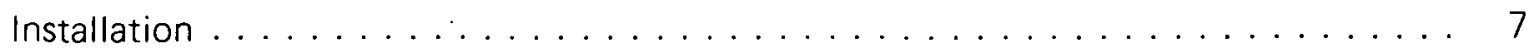

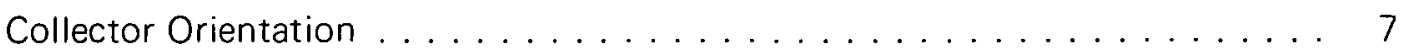

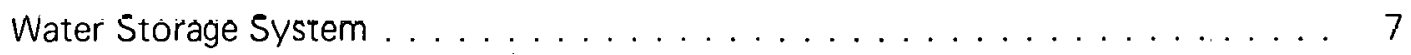

Electrical Modification . . . . . . . . . . . . . . . . . . . . . 8

Water Flow Meter . . . . . . . . . . . . . . . . . . . . . . . . . . . 8

Results ......................... 8

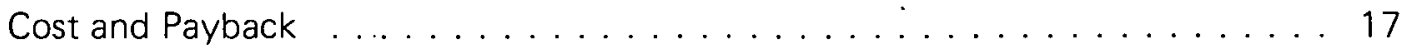

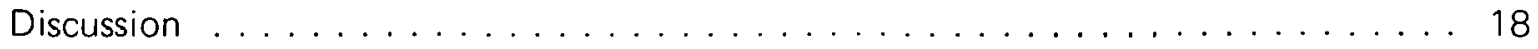

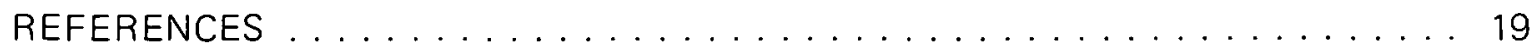

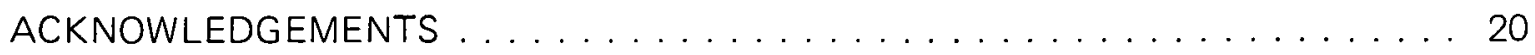




\section{SUMMARY}

A privately financed, double-glazed, flat-plate-collector-driven, solar-augmented hot water system was installed on an existing dwelling. It was determined that this family used about 30 gallons of hot water per day. Data were obtained on the collector water temperature, storage tank temperature, amount of hot water used, and amount of supplemental electricity required.

The $\$ 1500$ installation demonstrated that, for the hot water use rate of $30 \mathrm{gal} / \mathrm{day}$, the pay off would be less than 10 years with money borrowed at $10.5 \%$ and electricity costing 5 cents per $\mathrm{kWh}$. The system would not pay off in the TVA area at the 30-gallon-per-day use rate if electricity cost 2.5 cents per $\mathrm{kWh}$. It would pay off in less than 10 years with this low-cost electricity if the daily usage of hot water were to be doubled. 


\section{INTRODUCTION}

The reported cost and payback for solar water heating systems for existing residential houses are often grossly misstated. This misrepresentation has been a big holdback on public acceptance. The reason for this public reluctance is that few have really installed such a system and collected typical data that would establish the economic impact that such a system would have. Some experiments, like the one conducted by the New England Electric System, has drawn criticism from a number of sources due to design, installation, and operating problems. 1

The ERDA Division of Solar Energy, Washington, DC, has stated that cost-effective retrofit systems do not exist, nor are techniques readily available to facilitate the optimization of retrofit design. They state that many problems exist that require solution before the technology can be significantly advanced. ${ }^{2}$

Early in 1976 it was decided to install, as a private project, a solar water heating system on a 20-year-old house and collect data on collector temperature, storage-tank temperature, hot-water usage, and kilowatt hours of electricity saved. From these data it was hoped to obtain additional information on the economy of a retrofit system to an existing house.

It is obvious that more problems exist in a retrofit solar installation on an old house than in designing and incorporating a solar system into new construction. The problems encountered in an installation of this kind involve location and orientation of collectors, storage tank location, pipe runs and connections, and blending the system into the structure with acceptable aesthetic results.

The present study, conducted at the Oak Ridge $Y-12$ Plant, ${ }^{(a)}$ has produced an advance in solar water heating technology and has demonstrated the cost-effective design for a retrofit system for heating water for residential use.

(a) Operated by the Union Carbide Corporation's Nuclear Division for the US Energy Research and Development Administration. 


\section{ECONOMY OF A RETROFIT SOLAR SYSTEM}

\section{SOLAR SYSTEM}

Flàt-plate solar collectors and auxiliaries, supplied by Solar Research, Division of Refrigeration Research, Inc, were selected for this installation. These collectors combined steel plates and steel circulating tubes. The steel tubes were hydrogen copper brazed to the steel plate, and copper was fused over the steel plate surface at $2000^{\circ} \mathrm{F}$.

Each complete collector (eight panels in number and consisting of $10 \mathrm{ft}^{2}$ ) was contained in an aluminum case and had two inches of insulation behind the collector plate. The face of each collector was covered by an aluminum frame over which an envelope of 4-mil duPont Tedlar PVF (polyvinyl fluoride) was thermally shrunk to provide efficient double glazing. A diagram of the complete system is presented in Figure 1.

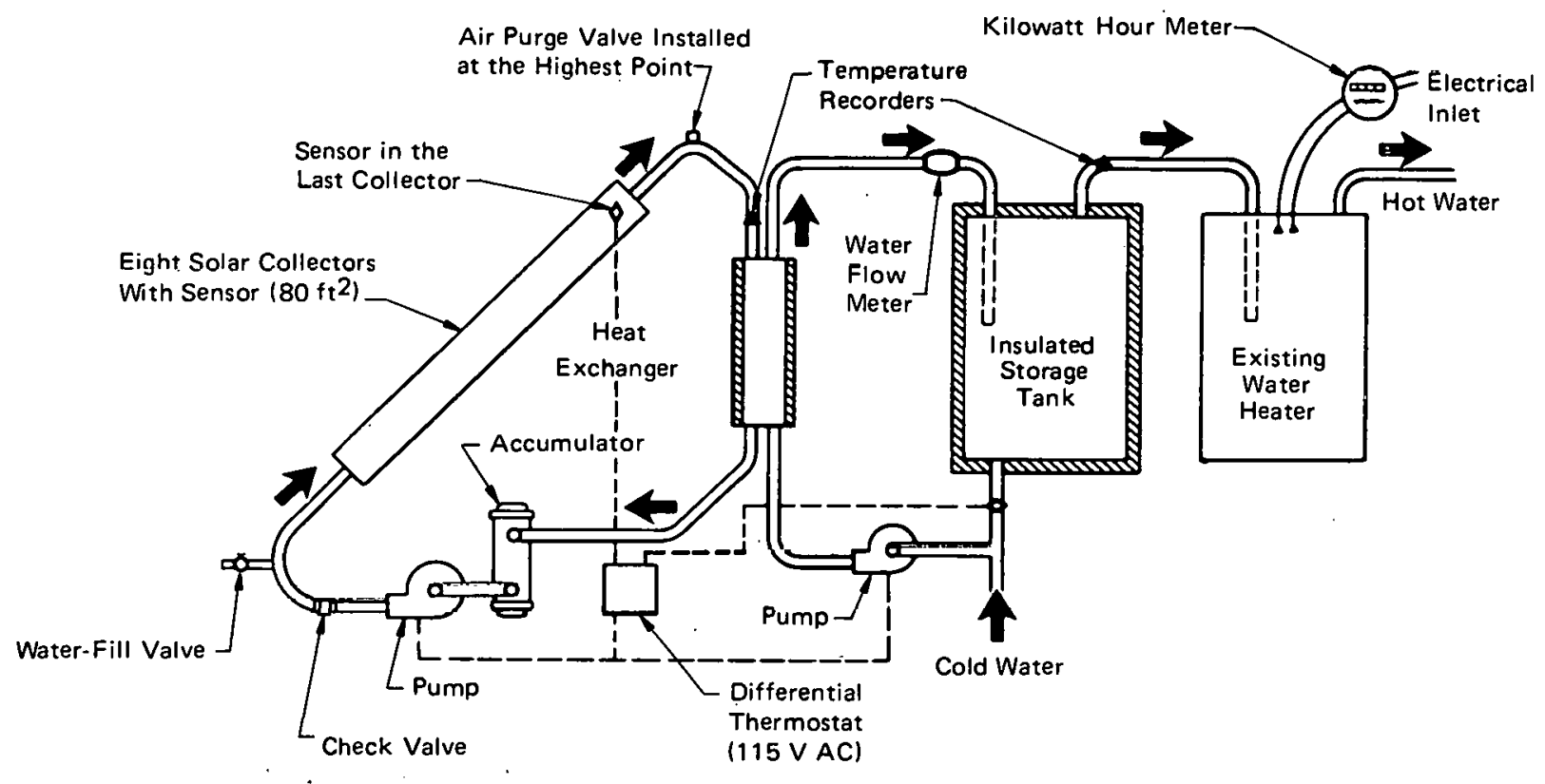

Figure 1. SOLAR WATER HEATING SYSTEM.

The circulating pump for the collector circuit was a magnetic-drive, water-circulating pump of $0.0154 \mathrm{hp}$. The circulating pump for the storage tank circuit was a magnetic-drive pump of $0.050 \mathrm{hp}$.

The heat exchanger contained a copper coil running through the steel case to prevent internal joints.

The differential thermostat control measured the exit water temperature from the collector and compared this with the temperature of the water in the storage tank. When the collector water temperature was greater than the water storage temperature $\left(\Delta t=20^{\circ} \mathrm{F}\right)$, the circulating pumps turned on; when the temperature differential was 
within $3^{\circ} \mathrm{F}$, the pumps turned off. This control assured that maximum heat energy was stored and retained in the tank under all weather and temperature conditions.

A 50/50 $\mathrm{glycol} /$ water fluid was circulated through the collector circuit at $0.3 \mathrm{gal} / \mathrm{min}$. Since the glycol-filled collector subsystem was a closed-loop, atmospheric-pressure-lifted syphon system, there was no pump head except for friction flow. The storage-tank, heat-exchange circuit was under house pressure (40 lbs) which assured that no glycol/water could leak into the potable water.

\section{INSTALLATION}

\section{Collector Orientation}

One of the most important parameters of solar radiation absorbance efficiency is the angular range over which radiation is accepted without moving all or part of the collectors. In planning the positioning of the collectors on this single family house, it was decided to use an available carport roof that is oriented south at an angle of 30 degrees to the horizontal. This location was the best one available, considering the house structure and the surrounding vegetation. It is estimated to have a maximum efficiency of only $75 \%$. Over the State of Tennessee there is little basis for variation in the solar energy received. (The latitude varies from $35^{\circ} 00^{\prime} \mathrm{N}$ on the Mississippi-Alabama-Georgia border to $36^{\circ} 40^{\prime} \mathrm{N}$ on the Kentucky-Virginia border.)

A chart was obtained from the Department of Geography, University of Tennessee, Knoxville, Tennessee. ${ }^{3}$. of the positions of the sun in the $36^{\circ}$ north latitude, which is roughly the latitude of Knoxville, Nashville, and Dyersburg. Tennessee (see Figure 2). (The times on this graph were based on solar noon.) This chart gives the location of the sun and its angle above the horizon for all months of the year.

Since it is more important to supplement the heat in colder weather, four collectors were positioned on the house due south (1800) at an elevation of 30 degrees above the horizon. A second set of four collectors was positioned 15 degrees east of south (165\%) and at a 40-degree elevation. This arrangement was used because of the nature of the location and in order to extend the hours over which radiation was accepted. This design allowed the pumps to turn on sooner in the morning and remain on later in the afternoon than could be obtained by a single, fixed position. Figure 3 is a picture of the collector assembled on the house.

\section{Water Storage System}

A 120-gallon galvanized water tank was installed and insulated with four inches of fiberglass insulation. The water inlet to the existing 55-gallon hot water heater was connected to the top of the storage tank and the cold water inlet was connected to the bottom of the storage tank (see Figure 1). This arrangement produced a total hot water capacity of 175 gallons. The water storage tank with the associated piping and instrumentation is seen in Figure 4. 


\section{Electrical Modification}

A kilowatt. hour meter was installed on the electric line to the existing hot water heater in order to determine the daily kilowatt hour usage.

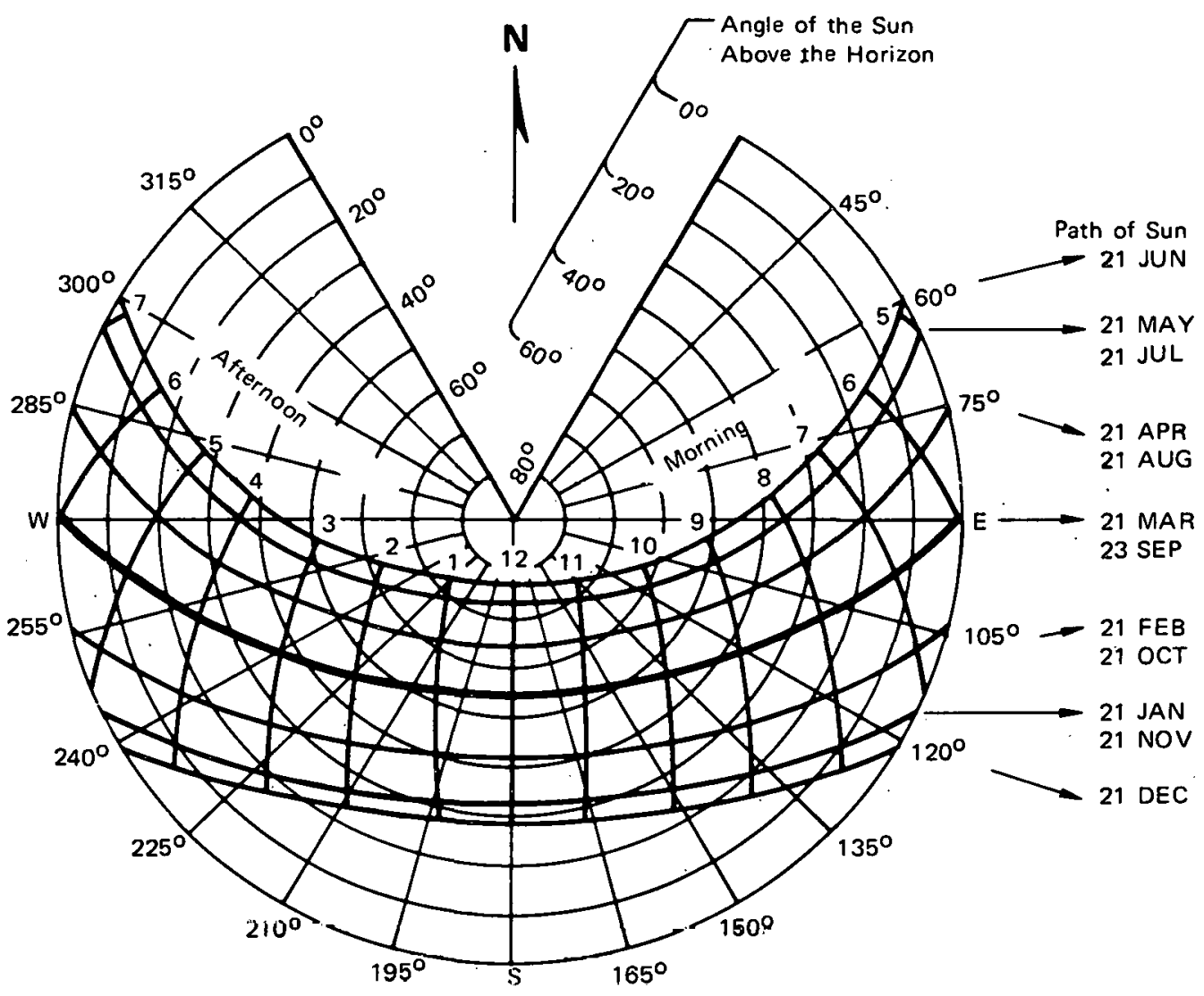

Figure 2. ANNUAL POSITION OF THE SUN AT 36 DEGREES NORTH LATITUDE. (Times are Based on Solar Noon)

\section{Water Flow Meter}

A water flow meter was installed in the water line between the storage tank and hot water heater. This position made it possible to keep a daily record of the amount of hot water used in the home (see Figure 4).

\section{RESULTS}

Prior to the installation of the solar hot water system, it was determined that $28 \mathrm{kWh}$ of electricity were required to heat the 55 gallons of water in the existing hot water tank from 50 to $155^{\circ} \mathrm{F}$ (the setting on the hot water heater). Since a well-insulated system 


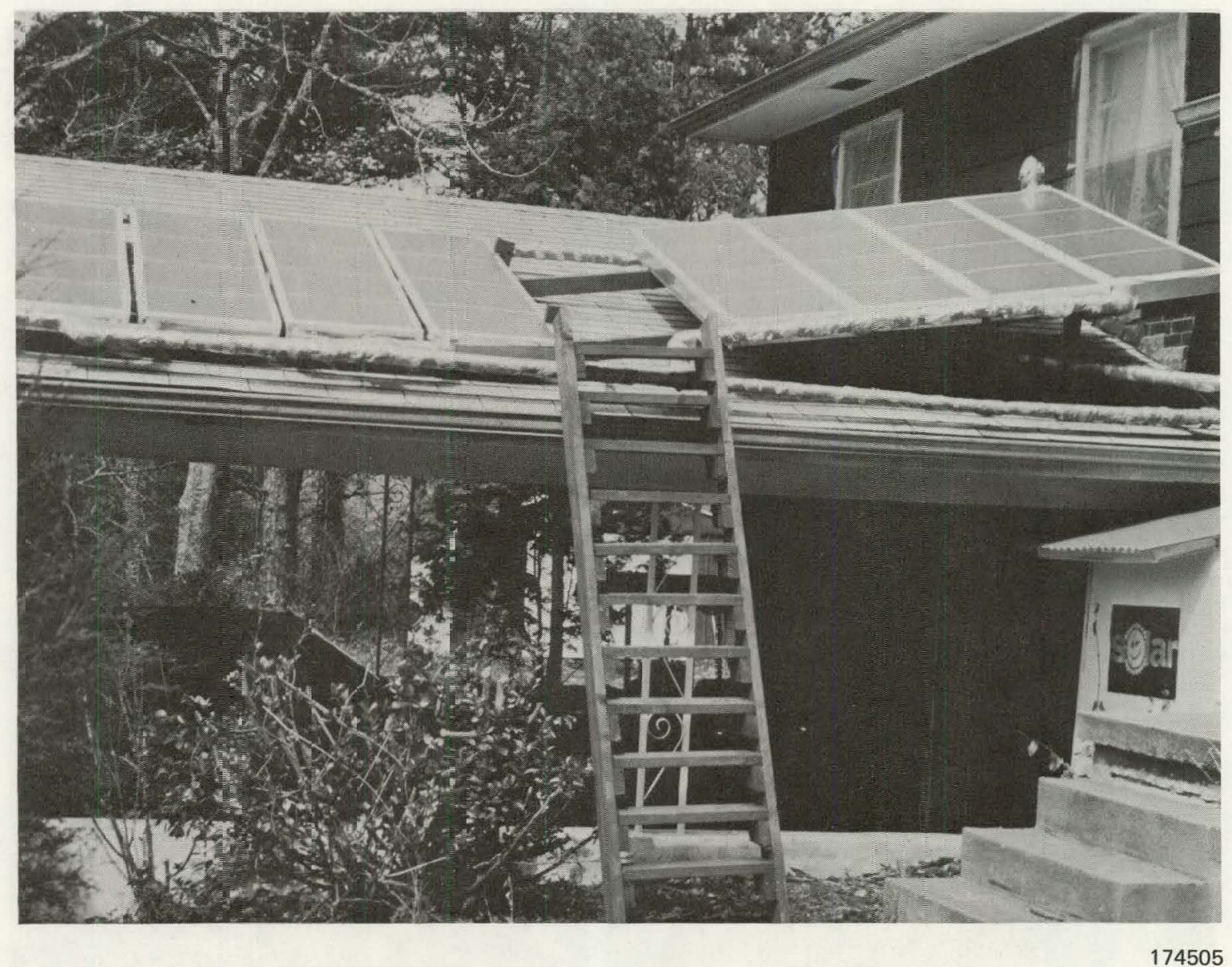

Figure 3. POSITION JF COLLECTORS ON THE ROOF OF THE CARPCRT 


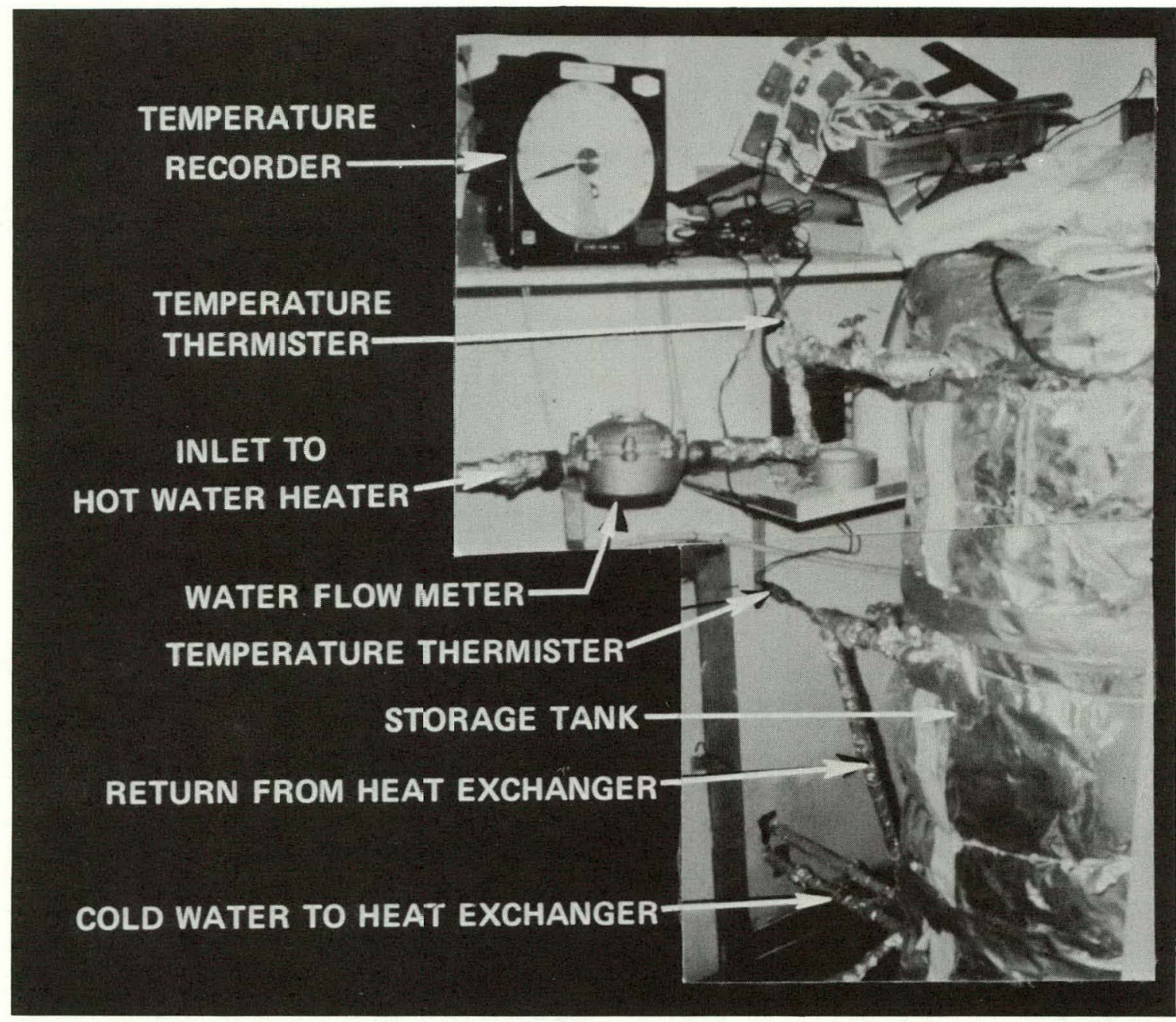

173467

Figure 4. WATER STORAGE TANK WITH ASSOCIATED PIPING AND INSTRUMENTATION. 
should require only $\sim 18 \mathrm{kWh}$, it indicated appreciable loss in the existing hot water system. Verification of this heat loss $(\sim 10 \mathrm{kWh})$ came during collection of solar heating data for March 1977 when the system remained stagnant while the occupants were away from home.

The average hot water used by this family of two, as recorded on the water flow meter, was 30 gals/day, meaning that about $15 \mathrm{kWh} /$ day were reyuired to hcat 30 gallons of water to $155^{\circ} \mathrm{F}$ in a hot water heater equivalent to the one used in this experiment.

The water temperature from the collectors $(0.3 \mathrm{gal} / \mathrm{min})$ for one day (January 30 , 1977, with three inches of snow on the ground and an outside temperature high of $27^{\circ} \mathrm{F}$ ) is indicated in Figure 5. As soon as the snow melted from the collectors (at 12 noon), the circulating pumps turned on and the water temperature rose to $130^{\circ} \mathrm{F}$. The water temperature from the collectors two days later is reported in Figure 6 . The temperature of the water on this day rose to $140^{\circ} \mathrm{F}$

Figures $7-12$ give the temperature of the water from the collectors, the storage temperature, and outside weather conditions for the monthis of February through July 1977.

Daily recordings of the kilowatt hours used to heat water in this house from March to July 1977 are included as Figures 13 through 17. In studying these data, remember that it was found that $28 \mathrm{kWh}$ were required to heat 55 gallons of water from 50 to $155^{\circ} \mathrm{F}$ in the existing hot water heater. A summary of the kilowatt hours saved during these months, based upon $15 \mathrm{kWh}$ used to heat 30 gallons of water to $155^{\circ} \mathrm{F}$, is given in Table 1 .

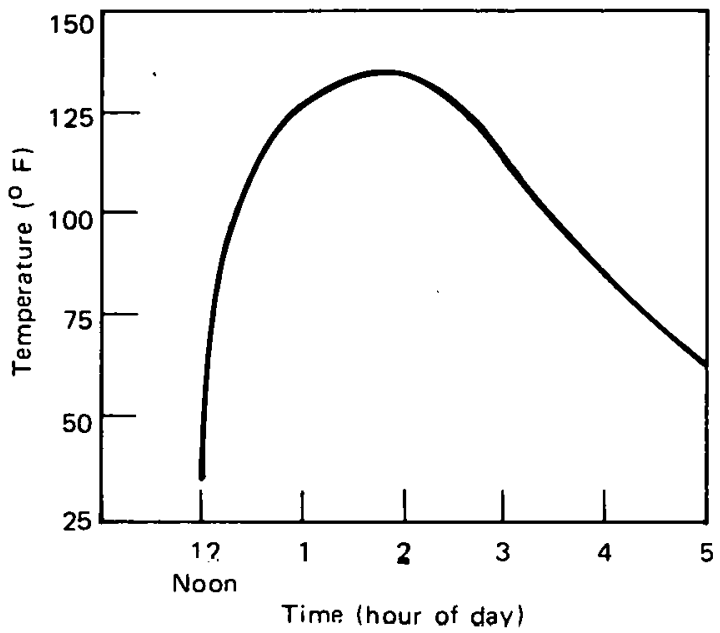

Figure 5. COLLECTOR TEMPERATURE RANGE FOR A WINTER DAY. (January 30, 1977; Maximum Air Temperature, $27^{\circ} \mathrm{F}$ )

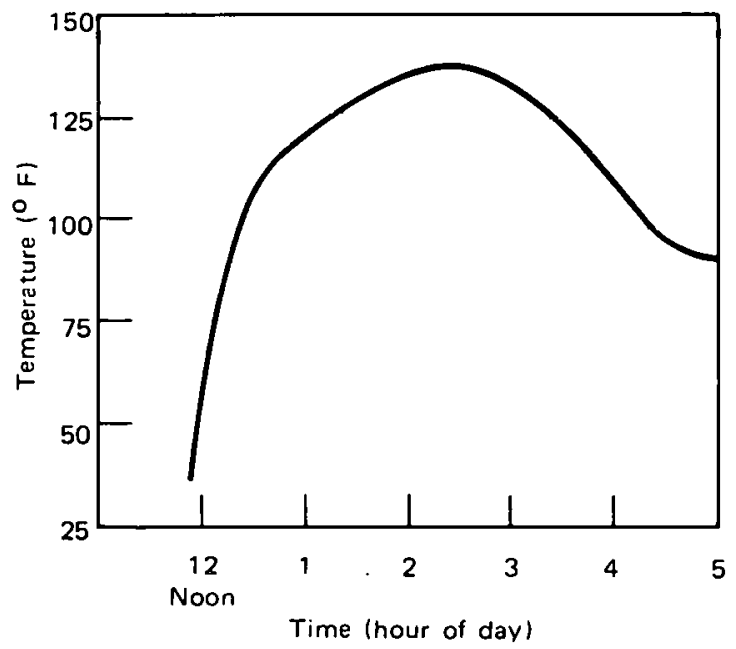

Figure 6. COLLECTOR TEMPERATURE RANGE FOR FEBRUARY 1, 1977.

Table 1

KILOWATT HOURS SAVED BY THE SOLAR WATER HEATING SYSTEM

\begin{tabular}{lcc}
\hline \multirow{2}{*}{$\begin{array}{l}\text { Month } \\
(1977)\end{array}$} & Used & Saved \\
\cline { 2 - 3 } & 69 & 366 \\
March & 20 & 415 \\
April & 18 & 447 \\
May & 8 & 457 \\
Jung & 3 & 462 \\
July & & \\
\hline
\end{tabular}




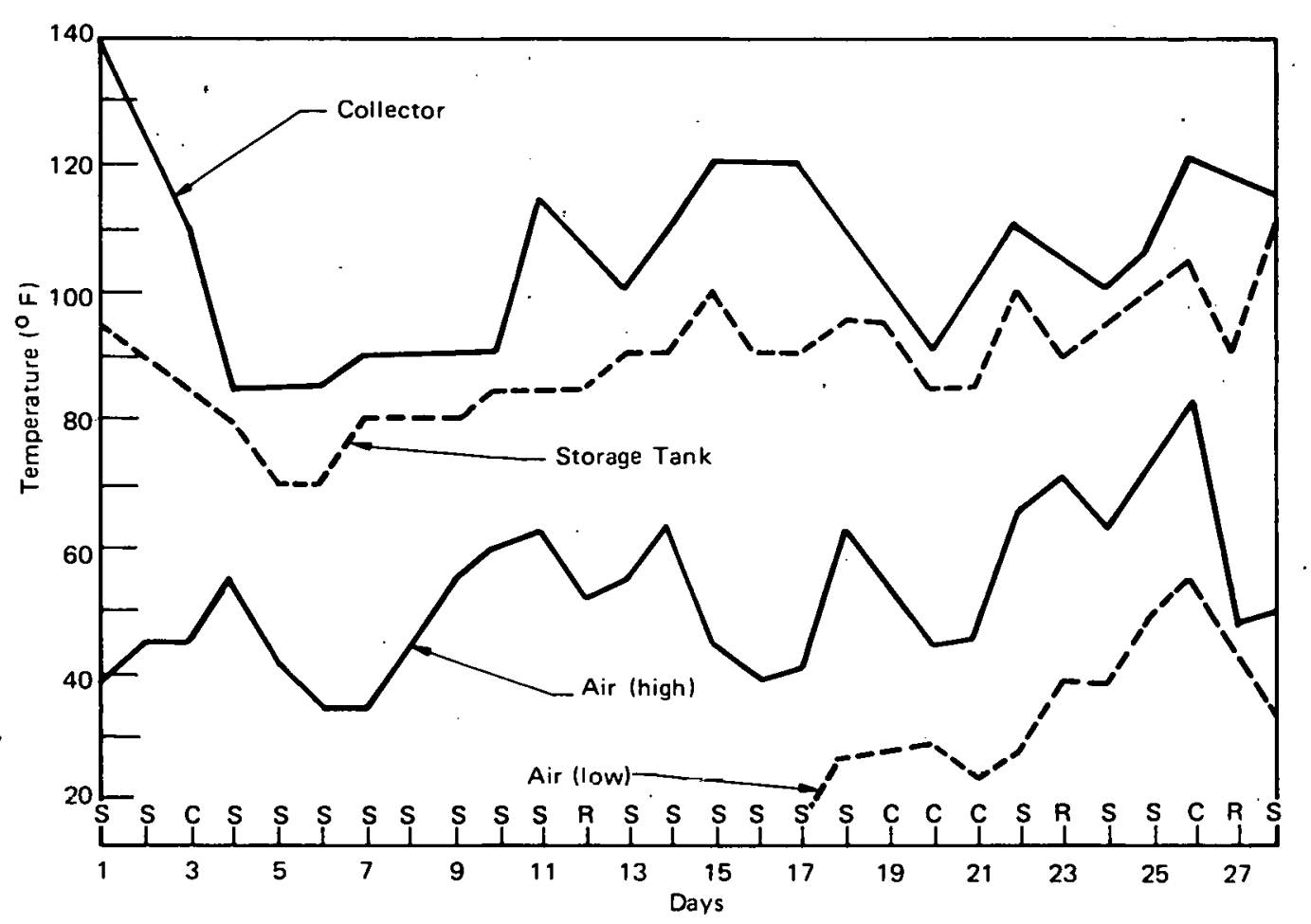

Figure 7. DATA ON THE SOLAR WATER HEATING SYSTEM. (February 1977)

R- Rain; C - Clouds; S - Sun

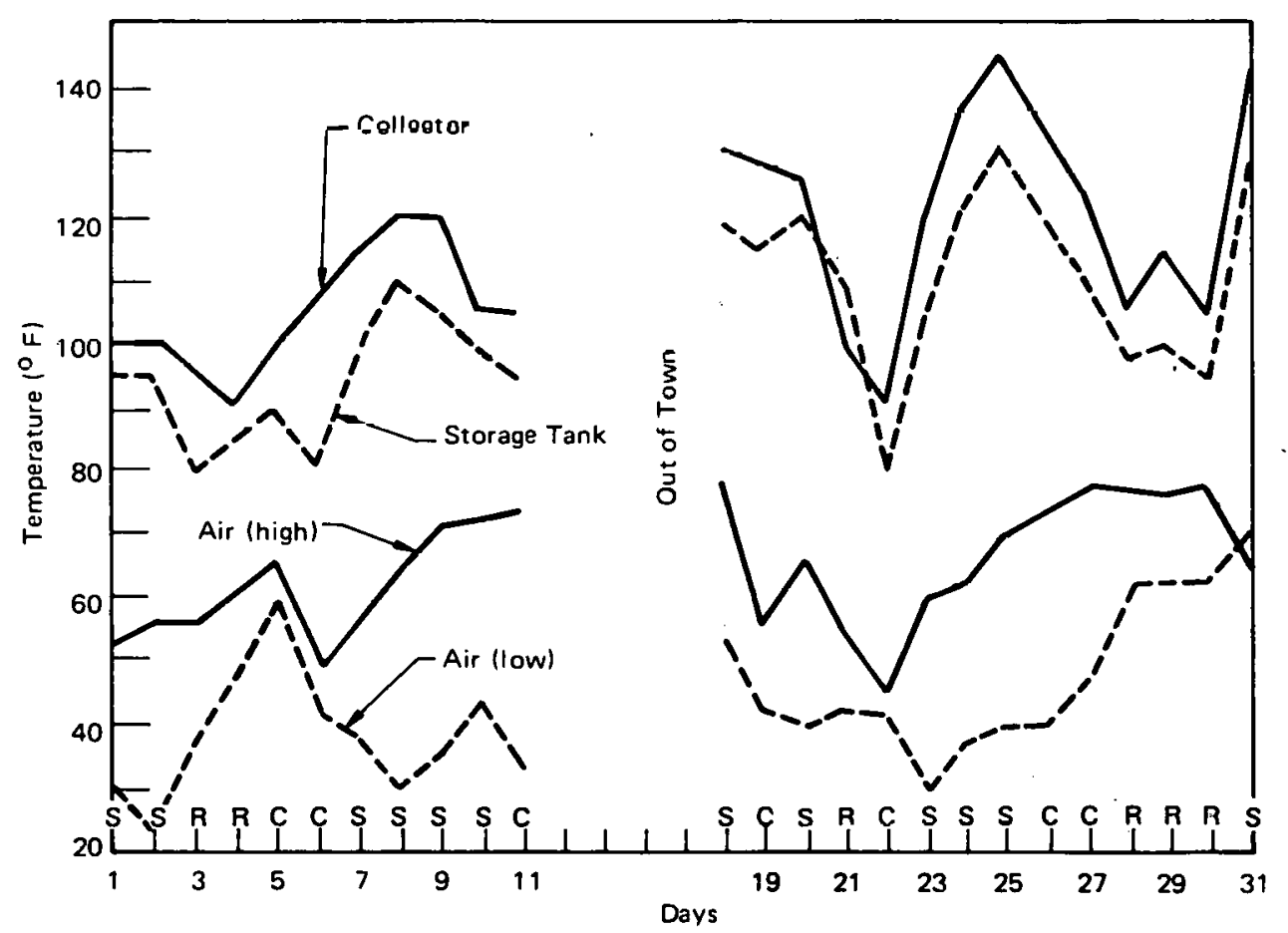

Figure 8. DATA ON THE SOLAR WATER HEATING SYSTEM. (March 1977) 


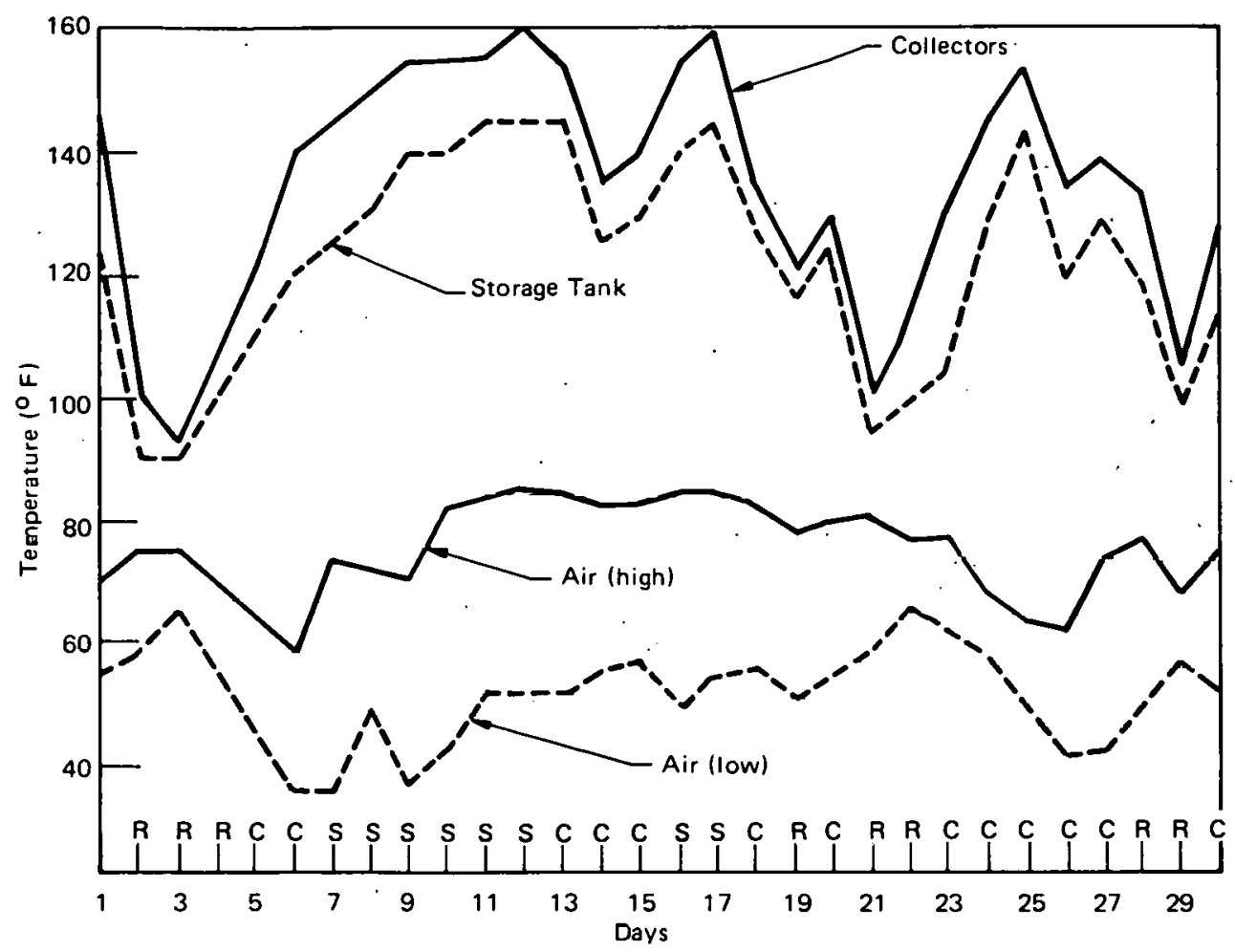

Figure 9. DATA ON THE SOLAR WATER HEATING SYSTEM. (April 1977)

R-Rain; C - Clouds; S - Sun

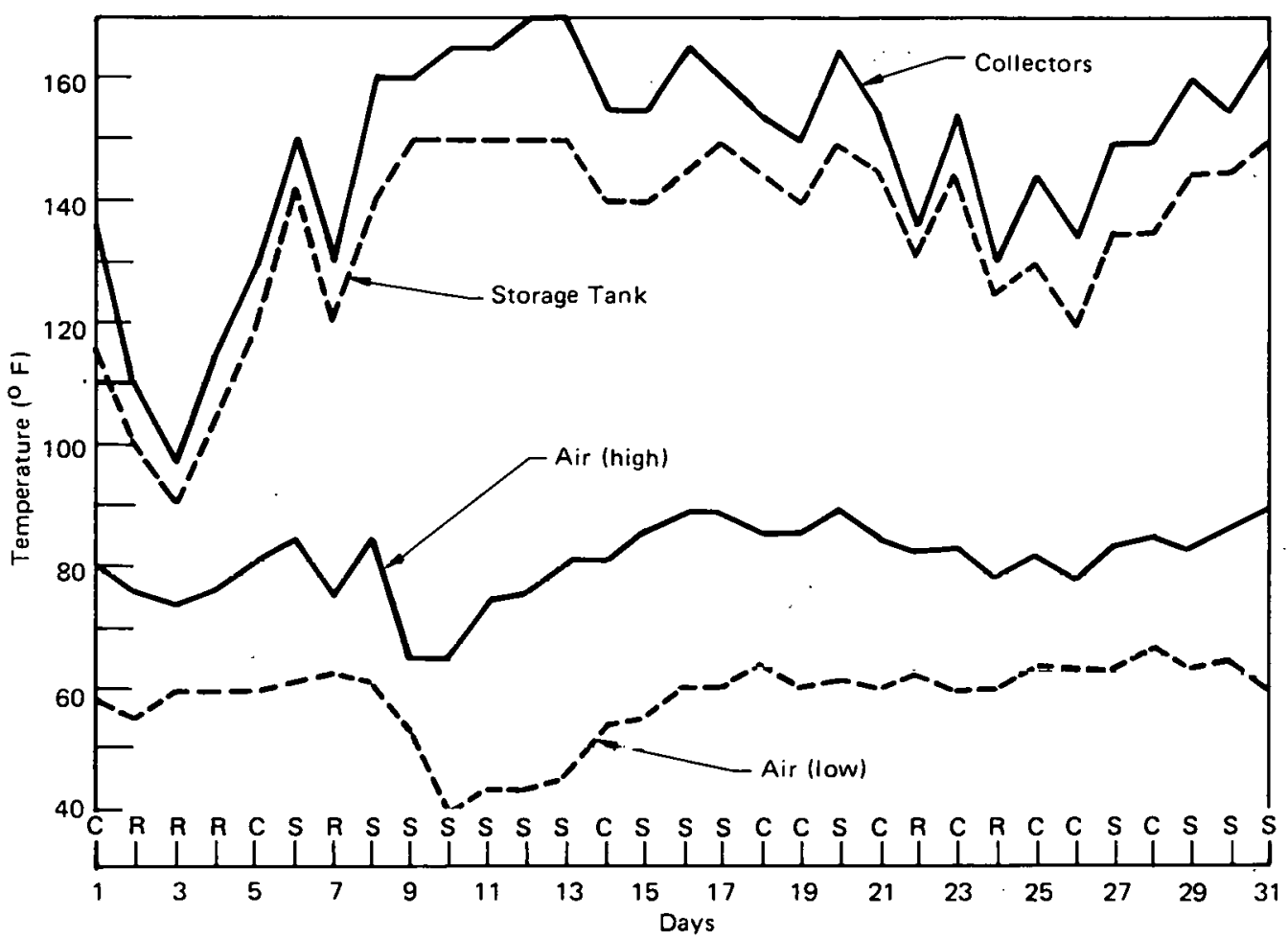

Figure 10. DATA ON THE SOLAR WATER HEATING SYSTEM. (May 1977) 


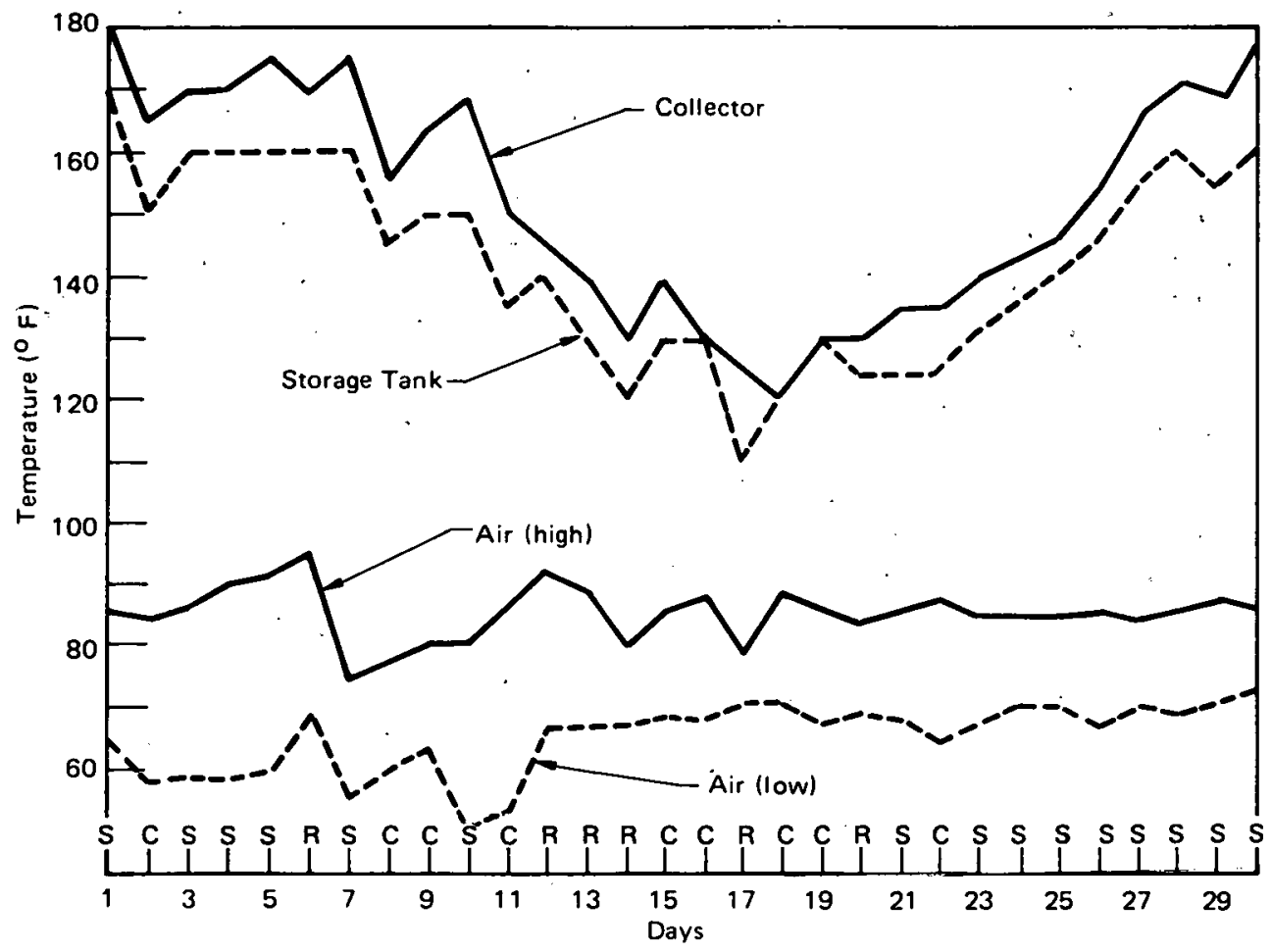

Figure 11. DATA ON THE SOLAR WATER HEATING SYSTEM. (June 1977) R-Rain; C- Clouds; S - Sun

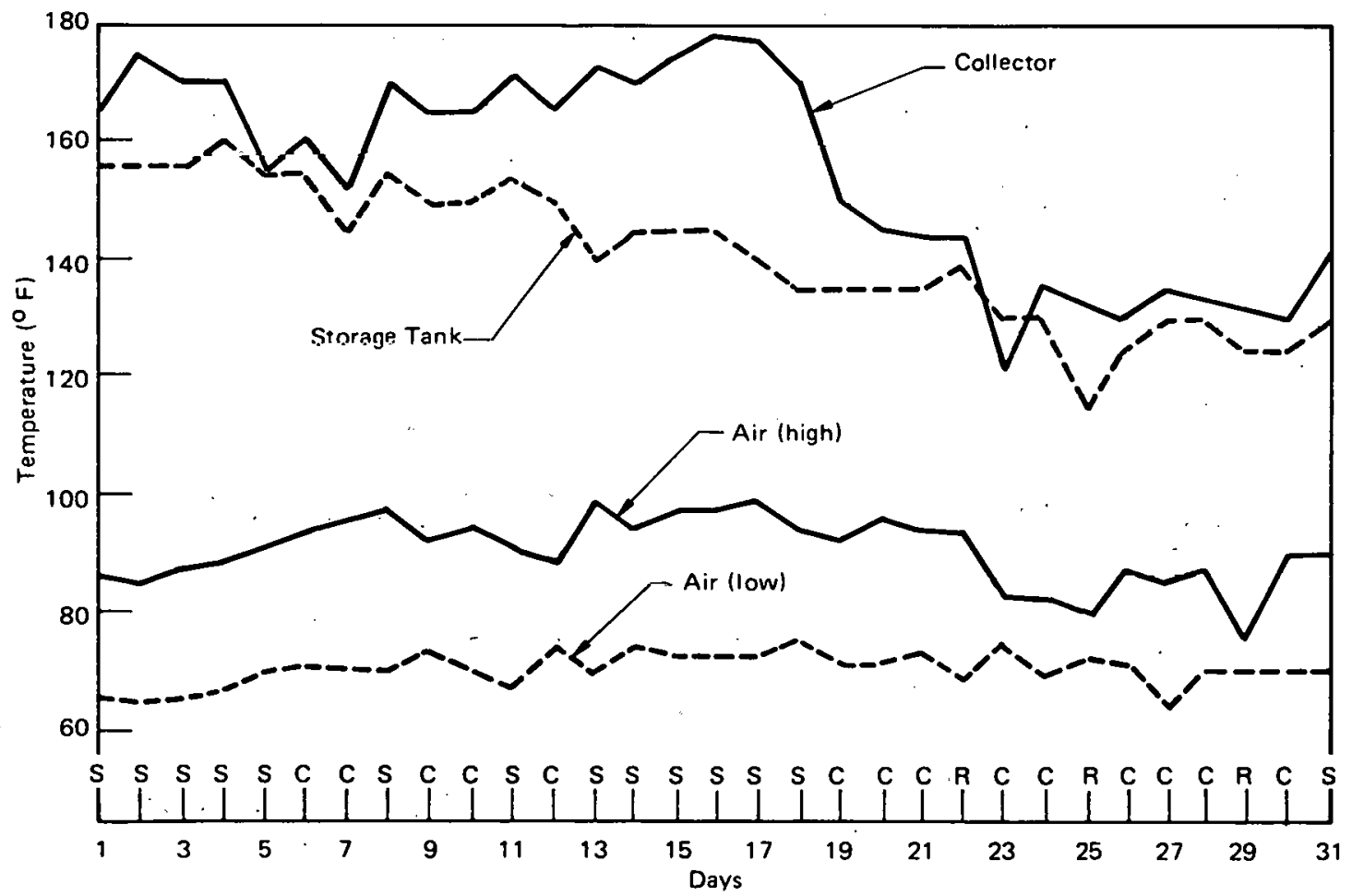

Figure 12. DATA ON THE SOLAR WÄTER HEATING SYSTEM. (July 1977) 


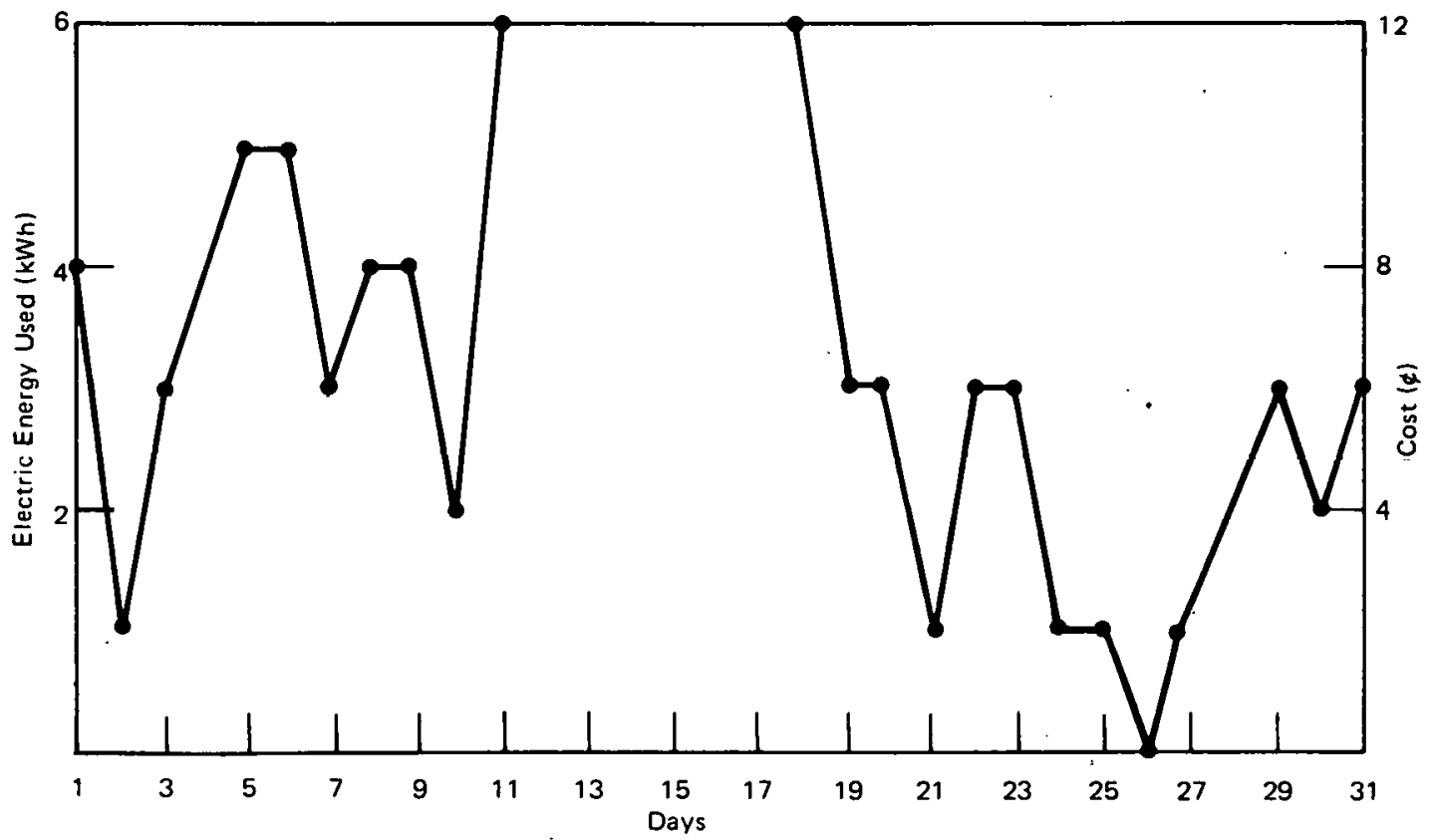

Figure 13. ELECTRIC ENERGY USED TO HEAT 55 GALLONS OF WATER TO $155^{\circ} \mathrm{F}$. (March 1977)

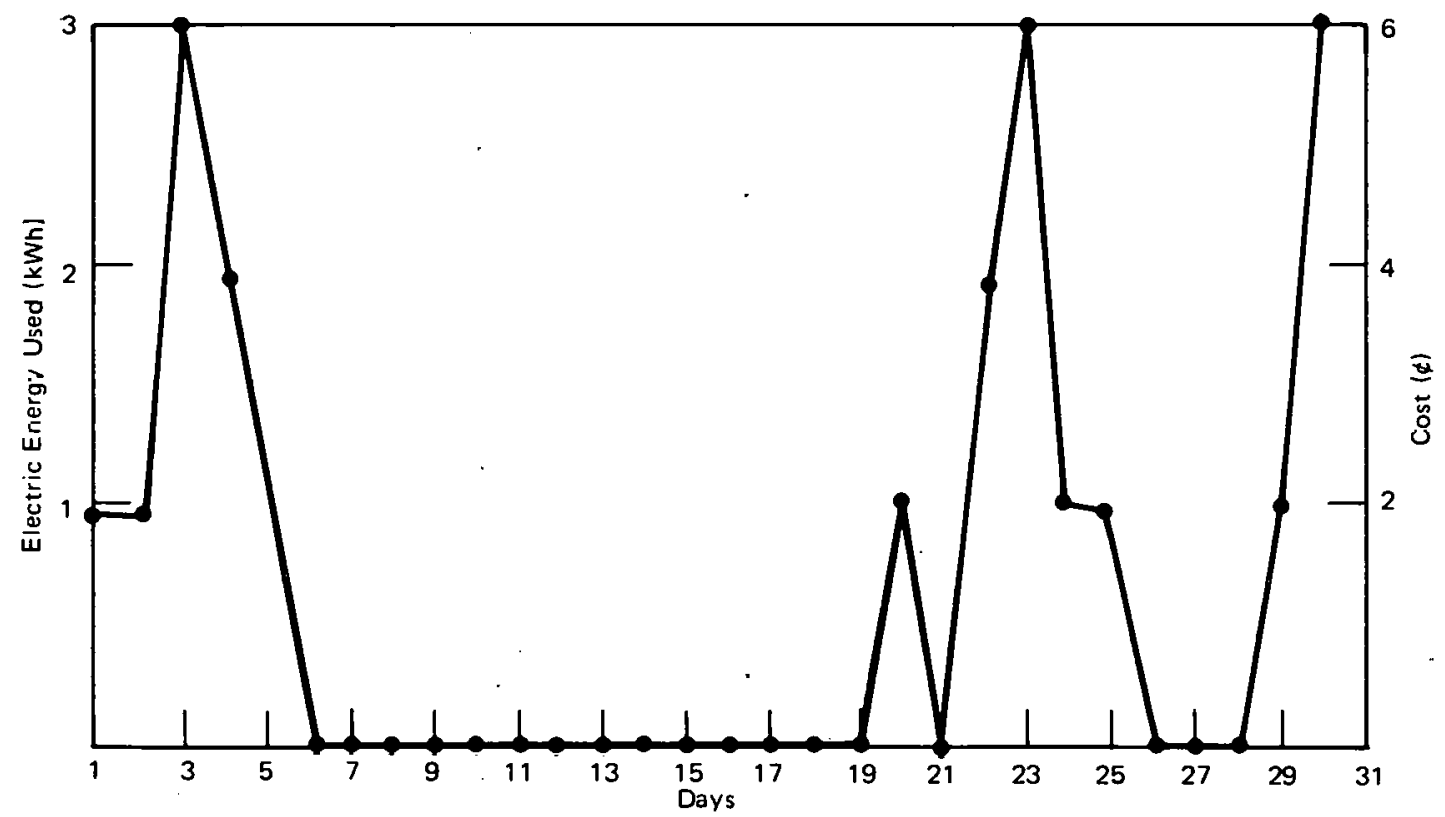

Figure 14. ELECTRIC ENERGY USED TO HEAT 55 GALLONS OF WATER TO $155^{\circ} \mathrm{F}$. (April 1977) 


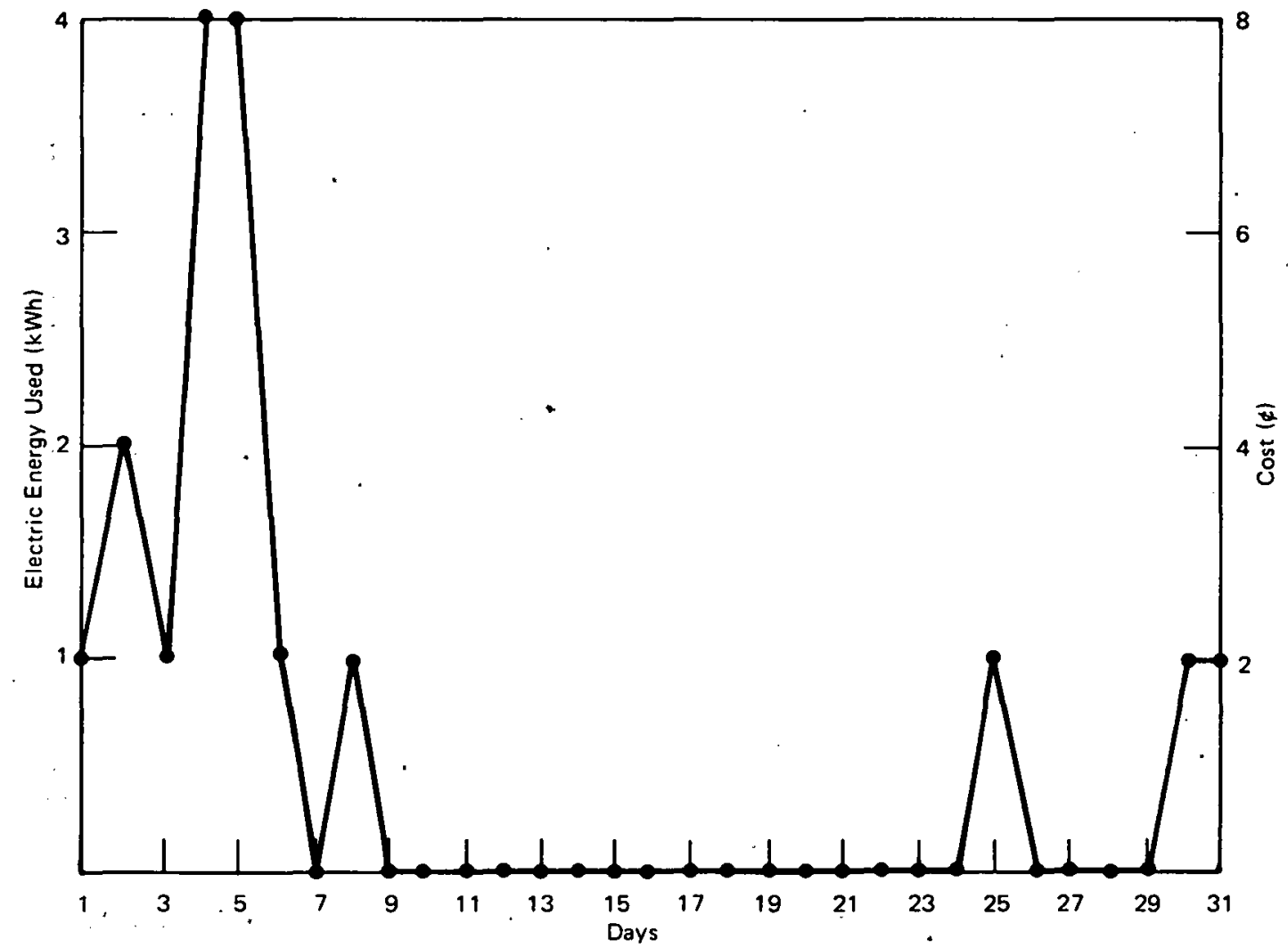

Figure 15. ELECTRIC ENERGY USED TO HEAT 55 GALLONS OF WATER TO $155^{\circ} \mathrm{F}$. (May 1977)

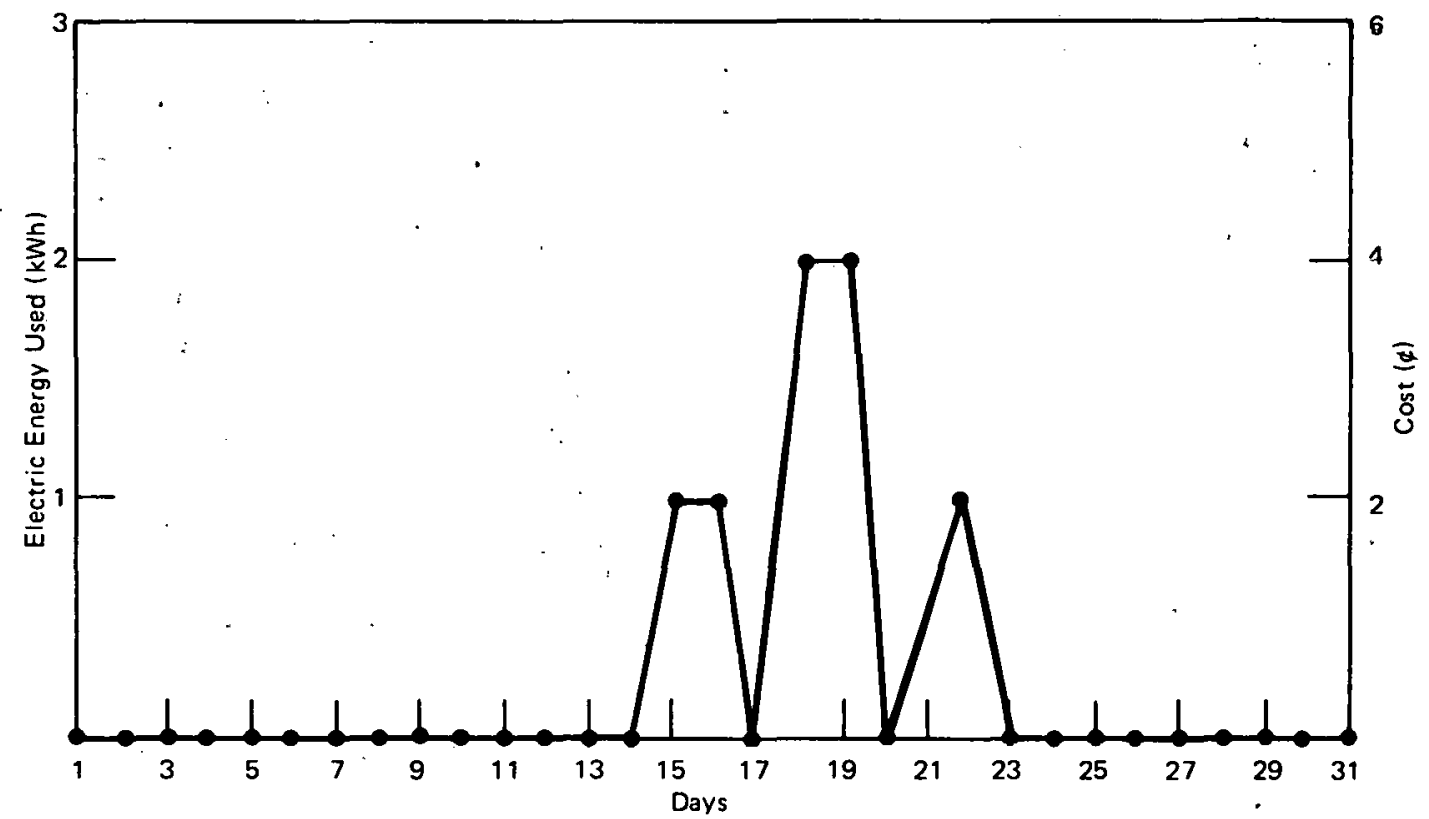

Figure 16. ELECTRIC ENERGY USED TO HEAT 55 GALLONS OF WATER TO $155^{\circ} \mathrm{F}$. (June 1977) 


\section{Cost and Payback}

The material and labor costs for this installation are reported in Table 2. The labor cost could vary, depending on whether the system was installed by the owner or by a contractor.

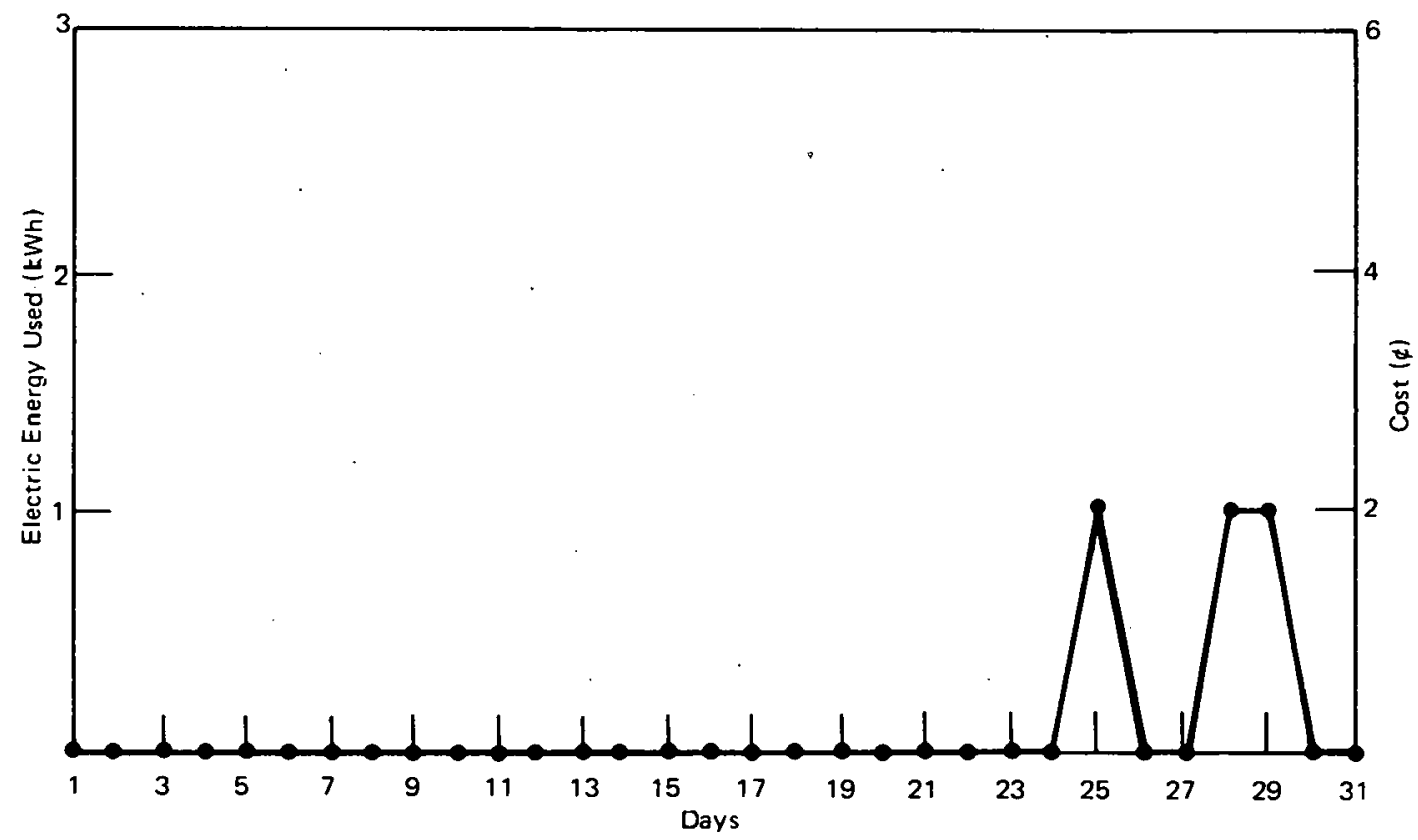

Figure 17. ELECTRIC ENERGY USED TO HEAT 55 GALLONS OF WATER TO $155^{\circ} \mathrm{F}$. (July 1977)

Utility rates vary widely over the United States; consequently, the cost savings and payback will likewise vary. In some areas, the electric rate is $10 \notin / \mathrm{kWh}$ while in others it is $2.5 \notin / \mathrm{kWh}$. Based on a daily usage of 30 gallons per day and a savings of $15 \mathrm{kWh}$ per day, an annual savings of $\$ 273$ would result if electricity cost $5 \not / k W h$.

An economic evaluation of a solar water heating system in the Tennessee area, from the housing consumer's point of view, is given in Table 3 . In this table it is assumed that the householder used from 30 to 55 gallons of hot water per day, the cost of electricity was 2.5 or $5 \mathrm{~d} / \mathrm{kWh}$, and the installation cost was financed at a 10.5 or $12 \%$ interest rate. These data demonstrate that, at a $55 \mathrm{gal} /$ day usage, the payback would come in approximately 10 years at $2.5 \not / \mathrm{kWh}$.

Table 2

COST OF MATERIALS AND LABOR FOR SOLAR WATER HEATER INSTALLATION
Eight Collectors

Water-Heating Package ${ }^{(1)}$

120-Gallon Storage Tank

Insulation

Labor $(20 \mathrm{hrs}$ at $\$ 6.37 / \mathrm{hr})$
Piping and Fittings

$\$ 739.76$

367.19

105.00

111.21

29.62

127.40

Total $\$ 1,480.18$

(1) The water-heating package consists of a combination heat exchanger/accumulator, a pressure-relief valve, a filler-drain valve, a primary pump, a secondary pump, a flow-regulating valve, a check valve, and a differential control with sensors. 
Table 3

PAYBACK PERIODS FOR SOLAR WATER HEATING

(At Two Electricity Cost Rates and Two Water Usage Rates)

\begin{tabular}{|c|c|c|c|c|c|c|}
\hline \multirow{2}{*}{$\begin{array}{c}\text { Hot } \\
\text { Water } \\
\text { Used } \\
\text { (gal/day) }\end{array}$} & \multirow{2}{*}{$\begin{array}{c}\text { Cost } \\
\text { Per } \\
\text { kWh } \\
\text { (d) }\end{array}$} & \multirow{2}{*}{$\begin{array}{c}\text { Solar } \\
\text { System } \\
\text { Cost } \\
\text { (\$) }\end{array}$} & \multirow{2}{*}{$\begin{array}{c}\text { Annual } \\
\text { Savings } \\
\text { (\$) }\end{array}$} & \multirow{2}{*}{$\begin{array}{c}\text { Annual } \\
\text { Maintenance } \\
\text { Cost } \\
\text { (\$) }\end{array}$} & \multicolumn{2}{|c|}{$\begin{array}{c}\text { Payback } \\
\text { Period (1) } \\
\text { (yrs) }\end{array}$} \\
\hline & & & & & at $101 / 2 \%$. & at $12 \%$ \\
\hline 30 & 5 & $1,480.18$ & 273.00 & 0 & $8.44^{\circ}$ & 9.28 \\
\hline 55 & 5 & $1,480.18$ & 501.88 & 0 & 3.71 & 3.85 \\
\hline 30 & 2.5 & $1,480.18$ & 136.50 & 0 & Never & Never \\
\hline 55 & 2.5 & $1,480.18$ & 250.94 & 0 & 9.67 & 10.86 \\
\hline 30 & .5 & $1,480.18$ & 273.00 & 50.00 & 11.96 & 14.05 \\
\hline 55 & 5 & $1,480.18$ & 501.88 & 50.00 & 4.22 & 4.41 \\
\hline 30 & 2.5 & $1,480.18$ & 136.50 & 50.00 & Never & Never \\
\hline 55 & 2.5 & $1,480.18$ & 250.94 & 50.00 & 14.87 & 19.00 \\
\hline
\end{tabular}

(1) Interest based on one of two FHA Home Improvement Loans-10 $1 / 2 \%$ plus insurance or $12 \%$ signature. Excludes pending income tax credit.

\section{DISCUSSION}

Many articles on solar-energy utilization describe its impact on the world energy crisis. It is felt that this is one of few attempts to date to present basic data that the general public can use to judge the economics of installing such a system on existing houses, using existing equipment technology.

Further Government support for private home demonstration projects, such as described in this report, is suggested as a means of providing the data needed to obtain acceptance by the public of the economics of using solar energy for providing hot water and heating of existing houses. 


\section{REFERENCES}

1. Solar Utilization News, 2, (2), p 17; August 1977.

2. Request for Proposals (RFP) Studies and Analysis of Systems for Solar Heating and Cooling Application, RFP-EG-77-R-04-0023; Division of Solar Energy, Washington, DC; September 16, 1977.

3. Reproduced by Permission of Dr. James R. Carter, Department of Geography, The University of Tennessee, Knoxville, Tennessee. 


\section{ACKNOWLEDGEMENTS}

The assistance of A. K. Van Hull, Y-12 Process Analysis-Department, in performing the economic analysis is gratefully acknowledged. 


\section{Distribution}

American Electroplaters Society, Inc

Schumacher, J. H., Jr

Energy Research and Development Administration - Oak Ridge

Hickman, H. D.

Leed, R. E.

Swisher, S. D. (ATDL)

Zachry, D. S., Jr

Energy Research and Development Administration - Washington

Kaplan, G. W.

Marvin, $\mathrm{H}$.

Morse, F. 1 .

\section{Lawrence Livermore Laboratory}

Nelson, W. E.

Los Alamos Scientific Laboratory

Hoyt, H. C.

\section{NASA - Lewis Research Center}

McDonald, G. E.

Oak Ridge Gaseous Diffusion Plant

Stief, S. S.

Wilcox, W. J., Jr

Oak Ridge National Laboratory

Beall, S. E.

Boercker, F. D. (100)

Brashear, $C$.

Chester, L. V.

Cliual, E. E.

Davis, R. M.

Faulkner, J. S.

Fischer, $\mathrm{H}$.

Fisher, T. C.

Hise, E. C.

Metz, H. J.

Postma, $\mathrm{H}$.

Weir, J. R., Jr

\section{Oak Ridge Y-12 Plant}

Armstrong, R. C. Briscoe, O.W. Burditt, R. B. DeMonbrun, J. R. Dodson, W. H. Duggan, H. G. Fraser, R. J. Hibbs, R. F. Huddleston, R. L. Jones, F.W. Keith, $A$.

Kite, H. T. (150)

Marrow, G.W.

Martin, W. R./Googin, J. M.

Mason, D. L.

McLaughlin, L. M.

McLendon, J. D.

Mills, J. M., Jr

Oakes, R. E.

Phillips, L. R.

Rhew, J. E.

Schmitt, C. R.

Schreyer, J. M. (100)

Smith, R. D.

Tewes, W. E.

$Y-12$ Central Files (master copy)

$Y-12$ Central Files (route copy)

$Y-12$ Central Files ( $Y$-12RC)

$Y-12$ Central Files (100)

Paducah Gaseous Diffusion Plant

Bewley, H. D.

Solar Research

Bottum, M. E.

Union Carbide Corporation - New York

Chambers, W. E.

Winters, C.

University of Tennessee-College

of Engineering

Stansbury, E. E.

In addition, this report is distributed in accordance with the Category UC-59, Heating and Cooling-Residential and Commercial Applications, as given in the USERDA Standard Distribution Lists for Unclassified Scientific and Techniçal Reports. TID-4500. 